\section{Computers for the Million}

ALL undergraduates, and not just those specializing in the seiences, should be taught how to use computers. This is the conclusion of a joint working party set up by the University Grants Committee and the Computer Board as much as anything because of concern about the widespread lack of awareness of the potential of computers (Teaching Computing in Tniversities. HMSO, $2 s 6 d)$. Although their blanket recommendation of programming experience for everybody may cause dismay among arts and social science students, undergraduate scientists will be glad that the inevitable introduction to computing occurs sooner rather than later. Too much time is lost by people having to start from scratch at postgraduate level. The justification for including non-scientists is that graduates from all disciplines take up posts in industry and government, where an understanding of computers is becoming increasingly important. Although it would obviously be preferable if everybody learnt the rudiments of computing at school, the working party, under Professor G. A. Burnard (University of Essex), is working on the principle of better late than never.

At present the chief obstacle to the spread of computer education at undergraduate level is a paper one. The machines supplied by the Computer Board, the chief source of computers for the universities, are limited by the board's terms of reference to use in research only. Several directors of computing labora. tories told the working party that they felt unable to increase the amount of teaching because of the board's terms. At the working party's recommendation the government has now agreed to extend the terms of reference to include the supply of computers for teaching. In a foreword to the report Mr Kenneth Berrill, chairman of the UGC, and Professor Brian Flowers, until recently chairman of the Computer Board, say that the extra hardware required between now and 1973 will mean an additional expenditure by the board of only about $f 1$ million, and that a start can still be made on carrying out the working party's recommendations. The report says that a realistic time for the introduction of elementary courses would be the session 1972-73.

'Teaching in computing at undergraduate level is at present patchy and thin, the report says, and at some universities non-existent. The report suggests that an introductory course should be run usually in a student's first year, preferably with the students having direct access to a computer through on-line consoles, although the report recognizes that, to begin with, most universities will have to settle for indirect access using card or paper tape inputs. This will mean devcloping compilers that allow a computer to handle a batch of simple programs that might be produced by a class of students more quickly than if the computer went through the normal operating procedure with each separate program.

It would be best, the report says, if the elementary courses were not taught by the staff of each university's computer laboratory but by the staff of the students' department. Departmental staff will be better able to stimulate the students with relevant applications of computing, but demonstrators should help the students with their programs.

\section{ART COLLEGES}

\section{Art without Design}

THe general malaise of art education, which has only been brought to public attention by the bitter and protracted disputes at Hornsey and Guildford colleges, is unlikely to be greatly alleviated by the long awaited report of the Coldstream Committee. The committce, under the chairmanship of Sir William Coldstream, has been looking into the whole structure of education in art and design, and it has published its recommendations this week (The Structure of Art and Design Education, HMSO, 7s).

The committee suggests, but without much discussion of the rationale behind the suggestion, that the present Diploma in Art and Design (Dip AD) should be substantially modified. Some of the design courses should be taught separately as four-year sandwich courses, with up to one year spent in industry, while the remaining courses should be flexibly grouped into four chief studies-fine art, graphic design, three-dimensional design and textiles/fashion. The committee lays considerable emphasis on the flexibility of the groupings, and suggests that students should be able to pursue a broader range of studies which cross or overlap the boundaries of the groupings. The sandwich courses, on the other hand, should have a "substantial specialized technological content which can best be studied in close association with the relevant industry or profession". Students should be able to transfer from the sandwich course to the Dip AD or vice versa only in exceptional circumstances.

The committee also suggests that students should be able to enter the sandwich courses after a good general education of sixth form standard, while those wishing to take the three-year Dip AD course must still take the one-year foundation course except in special circumstances. But the most grave and pressing problem at present facing the potential art student is that many more students leave the foundation courses in search of a diploma course than the diploma colleges can accommodate. It is this huge demand for places that creates much of the frustration and discontent in art education. What the committee proposes is essentially that the number of places in foundation courses should be limited: "some form of central control of foundation courses is necessary so that the number of people being prepared for diploma courses and the number of diploma places available relate more closely to cach other", and so the bottleneck will be shifted but not removed.

How does the development of the polytechnics, and the gencral expansion of further education affect the committec's recommendations? Unfortunately, the recommendations secm to have been made without much regard to-or at least without much discussion of - the rest of the education sector. To be sure, the report points out that there are some considerations which have not been included because the committee was anxious that its recommendations should be made as soon as possible, but a discussion of the part to be played by the art colleges in the polytechnies and some consideration of the interactions between art colleges and, for example, colleges of education seems a striling omission. 